This item was submitted to Loughborough's Research Repository by the author.

Items in Figshare are protected by copyright, with all rights reserved, unless otherwise indicated.

\title{
The ethics and politics of vulnerable bodies
}

\section{PLEASE CITE THE PUBLISHED VERSION}

http://www.euppublishing.com/book/9780748678846

\section{PUBLISHER}

Edinburgh University Press

\section{VERSION}

AM (Accepted Manuscript)

\section{PUBLISHER STATEMENT}

This work is made available according to the conditions of the Creative Commons Attribution-NonCommercialNoDerivatives 4.0 International (CC BY-NC-ND 4.0) licence. Full details of this licence are available at: https://creativecommons.org/licenses/by-nc-nd/4.0/

\section{LICENCE}

CC BY-NC-ND 4.0

\section{REPOSITORY RECORD}

Lloyd, Moya S.. 2019. "The Ethics and Politics of Vulnerable Bodies". figshare. https://hdl.handle.net/2134/19670. 


\section{The ethics and politics of vulnerable bodies}

\section{Moya Lloyd}

In an essay from 2000, Judith Butler confesses her worry that the 'return to ethics has constituted an escape from politics' (15). In a published conversation with the political theorist William Connolly from that same year, she makes a similar claim, commenting that 'I tend to think that ethics displaces from politics'. The nature of the problem as she sees it is that 'the use of power as a point of departure for a critical analysis is substantially different from an ethical framework' (Butler in Butler and Connolly 2000). How ironic, therefore, that several critics see Butler's own engagement with ethics in the same way: as a turn to ethics that heralds either a turn away from politics or its displacement. (See, for example, Dean 2008; Honig 2010, 2013; and Shulman 2011). Using this debate as the backdrop for this chapter, I want to plot a different route through Butler's discussion of ethics and politics, by way of the vulnerable body. As I see it, it is not that her ethical considerations lead her to abandon politics; in fact, she is at pains throughout her work to emphasise how power operates to regulate and determine who counts as human, to shape and condition the scene of recognition, and to circumscribe the types of ethical encounter that might take place there. Butler is thus fully aware of the 'ethical stakes' in 'political encounters' and of the 'political modalities' shaping 'ethical questions' (in Butler and Athanasiou 2013: 74), of the ways that politics and ethics are inter-imbricated. The difficulty is rather that there is a tension in her work between ethical responsiveness as an abstract potentiality arising from ecstatic relationality and existential precariousness and the actualisation of ethics and politics in specific contexts of politically induced precarity. Central to my discussion will be a consideration of the ambivalent way that the idea of corporeal vulnerability operates in her work. 
The body has been a core idea in Butler's work from her very earliest writings through to the most recent; however, her characterisation of it has been far from static or straightforward. She has, at various points, posited a phenomenologically-informed account of the body as an 'historical idea' (Butler 1989); an understanding of 'sex' and the sexed body as the effect of a binary 'gender apparatus' such that sex was 'always already gender' (Butler 1990: 7); a revised understanding of sex as a regulatory norm of embodiment related to, but different in its operations from gender (Butler 1993); and in what appeared to be a quite distinct and even unexpected turn in 2004 (Butler 2004a; 2004b), she offered a conceptualisation of the body as vulnerable, precarious, and what she has more recently termed 'socially ecstatic' (Butler 2011a). In fact, the theoretical antecedents of this conceptualisation can be found in The Psychic Life of Power (Butler 1997). It is this relational account of the body that I will focus on in this chapter. I am particularly interested in the paradox inherent in Butler's contention that the very circumstance that renders certain bodies unrecognisable as 'human' - namely their precariousness, albeit mediated through states of express precarity - is simultaneously the condition for embodied political action and ethical responsiveness.

In the first section of the chapter, I examine Butler's most recent thinking on the body, outlining the main characteristics of that thought and setting out the dualistic approach to vulnerability that I contend that Butler adopts here. This is followed by a discussion of the distinction that she draws between precariousness and precarity, and their relation to the politics of vulnerability. In the final two sections of the chapter, I consider first how it is possible to perform politics in conditions of precarity, exploring in particular Butler's debt to Hannah Arendt, and second what practising ethics in those same conditions might entail, focusing on whether Butler is able to explain what needs to be done to encourage ethical responsiveness in contexts where we are unable to 'see' particular persons as 'human' or 
'hear' their address. Throughout the chapter, I will relate my discussions to Butler's work on gender.

\section{Towards a 'new body politics'}

After 9/11 Butler started to make repeated calls for what she variously described as a 'new body politics' (2012a: 14), 'a different kind of bodily politics' (2012a: 13), and the basis for a revised 'progressive or left politics' (2009a: 2). Sometimes she couched this call in terms of the need for 'a new bodily ontology' (Butler 2009a: 2) or its 'rethinking' (Butler 2009a: 3); at others, she formulated it as a broader need to 'conceptualize the body in the field of politics' (Butler 2011a: 385) or, at least, to 'reconsider' how it is conceptualised (Butler 2009a: 52). Her avowed hope was that a reorientation of this kind might open up 'another kind of normative aspiration within the field of politics' (Butler 2004a: 26) and 'a different conception of politics' (Butler 2004b: 21). Why was this necessary? What was wrong with, or deficient about, the prevailing conceptualisation of corporeal politics that it required revising? Indeed, what according to Butler did this prevailing conceptualisation look like? In Frames of War, she provides a partial answer: 'We have to consider', she remarks, 'whether the body is rightly defined as a bounded kind of entity' (Butler 2009a: 52; see also 2011a: 385).

The idea of 'bounded'-ness, as Butler describes it, is intimately connected with two politically salient ideas: ${ }^{1}$ corporeal autonomy, where the capacity to demand rights over (the disposal of) our bodies depends on the sense that, in some way, we own them, that they are ours to control; ${ }^{2}$ and the ability to make anti-discriminatory claims on behalf of 'a group or a class', when, she declares, it is necessary to 'present ourselves as bounded beings - distinct, recognizable, delineated, subjects before the law' (2004a: 24). These ideas are, of course, integral to many political campaigns and to the movements that espouse them, from feminist calls for reproductive freedom, access to contraception and abortion, through demands for the 
right of 'intersex people ... to make their own decisions affecting own (sic) bodily integrity, physical autonomy and self-determination' (Third International Intersex Forum, 2013), to gay and lesbian demands for sexual freedom. Corporeal integrity and self-determination are seen to go hand-in-hand. One cannot live one's life as one chooses if someone or something else another person, institution, or the state - controls one's body, including both what is done by it and to it.

Butler is certainly sympathetic to the need to campaign for certain rights - she talks, for example, of the need to continue to 'maximize the protection and freedoms of sexual and gender minorities, of women, and of racial and ethnic minorities' (2004a: 26). Additionally, she acknowledges that it is nigh on impossible to make such demands without deploying the language of autonomy, and specifically corporeal autonomy (Butler 2004b: 21).

Nevertheless she discerns a problem with the way that 'certain notions of autonomy' have 'made us think about individuals as self-motored' (Butler in Butler with Taylor 2009: 210). In Undoing Gender, she indicates why: autonomy is problematic when it is assumed to signify 'a state of individuation, taken as self-persisting prior to and apart from any relations of dependency on the world of others' (Butler 2004b: 32). The difficulty, she explains, is that ‘the body does not belong to itself and never can' (Butler 2011a: 385). To survive, bodies depend from birth on what is outside or beyond them.

When Butler calls for the development of a 'new' conceptualisation of the body and a new bodily politics, based on a 'new' corporeal ontology, therefore, she is not calling simply for a dismissal of (bodily) autonomy and its associated claiming of rights; bodily autonomy, as she sees it, is 'a lively paradox' (Butler 2004b: 21; see Chambers and Carver 2008: 71), something that must be claimed just as it needs to be disclaimed. Her goal rather is to champion their rethinking on the assumption of the body's fundamental dependency.

Questioning whether it is possible to talk of the 'being' of the body, Butler speculates 
that if it is, then this 'being' is that the corpus is 'always given over to others, to norms, to social and political organizations' (2011a: 382; see also 2004b: 21). For Butler this emphasis on the sociality of the body is important ontologically. As indicated, in her terms the body is never simply one's own. It is always impinged upon from outside: by others, known and unknown, distant and proximate; by social norms; by historically specific conditions of embodiment; by social and political organisations; and by environmental factors. Bodies, in fact, exist 'not only in the vector of these relations but as this very vector' (Butler 2011a: 385 my emphasis). Consequently, the flesh is always already public and social - both the individual's corpus and yet not its own at the same time, bounded yet simultaneously unbounded, impermeable yet permeable. As such, Butler reasons, the body has no essence per se. Rather the ontology of the body, as she apprehends it, is a 'social ontology' (Butler 2011a: 382, original emphasis; see also Butler 2009a: 3).

Although it might appear that Butler is advancing a relational account of the embodied subject, she is not merely contending that fleshy selves 'have' relations with other fleshy selves that somehow define them, affect them, or shape them into the embodied entities they are. As her discussion of the body-as-vector intimates, her claim is rather that the corporeal self "“is"” its 'relation to alterity' (Butler 2004b: 150, my emphasis); it is constituted in and by these relations. Without the 'forming and unforming' of 'bonds' with others (Butler 2009a: 182) there would be no subject. These bonds are the very condition of possibility for subjectivity, socially, affectively, and psychologically. It is its relation to alterity that enables the corporeal subject to desire, to experience passion, to be affected by and to affect others, and to act; in short, to exist.

As I have argued elsewhere (Lloyd, 2007), Butler is indebted in her thinking here to the idea of ecstasy or ek-stasis, which she construes as 'to be transported beyond oneself by a passion' or to be 'beside oneself' (2004b: 20, original emphasis). ${ }^{3}$ For Butler, ecstasis is 
ontological (2004b: 150): the embodied subject is beyond itself from the beginning. In The Psychic Life of Power, she explores this in terms of psychic subjectivity. The subject first emerges, Butler suggests, as a result of its 'passionate attachment' to those on whom it depends for its survival, such as its initial carers (1997: 7; for further discussion see Lloyd 1998-99), a dependency that must be disavowed if the subject is to attain full subjectivity. ${ }^{4}$ The subject's ecstatic existence continues as it experiences desire, passion, grief, rage, or love, experiences that 'undo' it, and as its body is dispossessed through the senses, as tactile, visual, auditory, haptic, olfactory capacities 'comport us beyond ourselves' (Butler in Hark and Villa 2011: 200; Butler 2012a: 16; see Butler 2004a: 24). Being 'undone' or dispossessed by another is not just a source of 'anguish', however; potentially at least, it is 'also a chance' of transformation, 'our chance of becoming human' (Butler 2005: 136; see also Stark 2014. I will return to the significance of this claim shortly.) The relationality Butler talks of, therefore, is 'ecstatic relationality' (Butler in Hark and Villa 2011: 200).

Butler's reconceptualisation of the body also rests on the idea of vulnerability; indeed, it is precisely corporeal vulnerability that makes possible ecstatic relationality, and thence ethics and politics. Butler is usually read by critics as equating vulnerability primarily, even exclusively, with susceptibility to harm or injury. Bonnie Honig's characterisation of her as a 'mortalist humanist', for example, rests precisely on the contention that Butler privileges the 'ontological fact of mortality' and 'vulnerability to suffering' (2013: 17; see also Honig 2010) while simultaneously neglecting a natalist emphasis on pleasure, desire, and hunger. Ann Murphy, who defines Butler as a 'corporeal humanist', describes her as figuring the body 'as an entity that is - above all else - vulnerable to injury and suffering' (2011: 577). ${ }^{5}$ George Shulman talks of Butler's emphasis on 'mortal vulnerability' or 'mortal precariousness', and of her ethics as 'oriented by a finitude that binds us to (the suffering and mortality) of others' (2011). 
Reading Butler's last few books, it is easy to see why critics might stress suffering and mortality. Precarious Life was composed in response to the terrible events of 9/11, and Frames of War, is explicitly concerned with questions of grievability. Yet the assumption that detrimental effects necessarily flow from corporeal vulnerability means that another, admittedly less prominent, aspect of Butler's argument is overlooked. This is what corporeal vulnerability makes possible.

The discussion of ecstatic subjectivity demonstrated that to be vulnerable for Butler is to be exposed to what is beyond or outside the self; indeed the body, for her, is 'vulnerable by definition' (Butler 2009a: 33). Vulnerability, however, is not synonymous with or reducible to injurability (Butler 2009a: 34, 61). ${ }^{6}$ In fact '[a]ll responsiveness to what happens', she declares, 'is a function and effect of vulnerability' (Butler 2012a: 16, my emphasis), including 'all the various ways in which we are moved, entered, touched, or ways that ideas and others make an impression on us' (Butler in Hark and Villa 2011: 200). Vulnerability in this sense is also the condition of possibility for love, desire, care, hope and life, the very natalist features that Honig largely fails to discern in Butler's work. ${ }^{7}$ To make sense of Butler's wider discussions of agency and resistance, and of politics and ethics we have to acknowledge this more expansive apprehension of vulnerability - as the ecstatic capacity to be affected by and to affect others (Gilson 2011).

Butler's revised account of corporeality as vulnerability thus brings to the fore a number of features: that because of their relationality bodies are 'invariably in community' with other bodies, that relationality is 'a descriptive or historical fact' of subject formation, and, most importantly given the concerns of this chapter, that relationality is an 'ongoing normative dimension of our social and political lives', one that requires us to take account of our interdependence (Butler 2004a: 27). For my purposes here, however, there is one final 
feature of Butler's reconceptualised account of corporeality that needs addressing; this is the concept of precarity.

\section{From precariousness to precarity and precaritisation}

Butler's focus on the body in sociality has the effect, as we have seen, of drawing attention to the vulnerability of somatic life. Simply pointing to the existence of a generalised condition of shared somatic vulnerability, says little, however, about the body in politics or the political body. In her earlier discussions, Butler spoke primarily of corporeal 'vulnerability’ or of 'precariousness' (2004a, 2004b). In Frames of War, however, she introduces a distinction that seems to me to be designed to capture the politics of vulnerability. Whether it does so or not is moot. This is the distinction between 'precariousness' and 'precarity'. Butler designates 'precariousness' as a 'more or less existential conception' (2009a: 3) or 'general feature of embodied life' (Butler in Kania 2013: 33), signalling a common vulnerability shared by all bodies.

This is in contrast to what she describes as the "more specifically political notion of "precarity" (Butler 2009a: 3), or the way that "precariousness is amplified and made more acute under certain social policies' (Butler in Kania 2013: 33). Precarity thus references the differential condition whereby some lives are rendered more insecure, unequal, or destitute

than others. ${ }^{8}$ Calling on Foucault, in the essay 'Can one lead a good life in a bad life?', Butler thus explicitly tethers precarity to biopolitics, 'those powers that organize life' and that 'establish a set of measures for the differential valuation of life itself' (2012a: 10). In contrast to her more generalised notion of precariousness, therefore, 'precaritization', Butler's term for the 'process of acclimatizing a population to insecurity' (Butler in Butler and Athanasiou 2013: 43), involves the social and political organisation of corporeal need and bodily interdependency in specific, concrete, and historically delimited ways. 
Precarity and precaritisation are interesting terms for Butler to deploy given their recent lexical history. ${ }^{9}$ As a political concept, the term 'precarity' has been deployed, mainly in a European context, to denote 'the financial and existential insecurity arising from the flexibilisation of labor' under post-Fordism (Brophy and de Peuter 2007: 180). ${ }^{10}$

'Precarization', an English neologism of the French term 'précarisation', refers to what Pierre Bourdieu in 1998 described as a 'mode of domination of a new kind, based on the creation of a generalized and permanent state of insecurity' for workers (Bourdieu cited in Brophy and de Peuter 2007: 183); while a third term, the 'precariat', is used to designate a 'new kind of political subject' (Neilson and Rossiter 2008: 52). This is a vocabulary embedded in political economy. There are certainly echoes of these meanings in Butler's employment of this lexicon: she often mentions, for instance, a 'disposable' or 'dispensable' workforce (Butler 2012a; Butler in Puar 2012; Butler in Kania 2013); she attends more to economic questions in Dispossession; and, she appears aware of their context-specific usage (see particularly Butler in Hark and Villa 2011; and Butler in Kania 2013).

But Butler uses precarity and precaritisation in a somewhat different, and potentially more ambitious way, to encompass not only the insecurities arising from changing labour conditions but as a way to register the diverse "modes of "unliveability"' (Butler 2012a: 12) that scar the contemporary scene, described by Athena Athanasiou in terms of 'socially assigned disposability' and 'various modalities of valuelessness' (Athanasiou in Butler and Athanasiou 2013: 19). One way to understand this emphasis, I propose, is to see it in terms of what I call the political problem of the human.

Cast in terms of Butler's own philosophical language, this problem centres on the recognition-recognisability nexus. Drawing from Hegel, she proposes that recognition be understood as 'an act or practice undertaken by at least two subjects' that 'constitutes a reciprocal action', whereas recognisability is her term to delineate 'those general conditions 
on the basis of which recognition can and does take place' (Butler 2009a: 6). Thus 'norms of recognizability prepare the way for recognition' (Butler 2009a: 7). Her point, as I have discussed elsewhere, is that norms of recognisability determine who is eligible for recognition (Lloyd 2007: 147): who, that is, is 'intelligible' as 'human'. For Butler there is, as such, a direct connection between the recognition/recognisability couplet and precarity, which is that 'the differential distribution of norms of recognition directly implies the differential allocation of precarity' (Butler in Butler and Athanasiou 2013: 89). Those who are not 'recognisable' as 'human' are more precarious than those who are.

From her earliest writings on gender, Butler has always been interested in the dangers attaching to those enactments of gender that contest or deviate from reigning heteronormative norms. In an essay from 1988 she observes how the presence of a 'transvestite on the seat next to us on the bus can compel fear, rage, even violence' (Butler 1988: 527). In Bodies that Matter (1993), she retells the story of Venus Xtravaganza, a pre-operative Latina trans(sexual) woman whose murder in 1988 has never been solved. In the 1999 Preface to Gender Trouble she highlights, for instance, the violence of gender norms against those with anatomically anomalous bodies (Butler 1999). Undoing Gender is replete with further examples: the killings of Brandon Teena, Mathew Shephard, and Gwen Araujo; ${ }^{11}$ the use of surgical intervention to 'correct' intersexed conditions; the story of David Reimer; ${ }^{12}$ and psychiatric diagnoses of gender disorders. In all of these diverse, and usually briefly documented cases, Butler's goal is to show the hazards faced by - or what she come to call the 'precarity' of - corporeal figures who do not fit neatly into (hetero)normative categories of sex, gender, and sexuality, and who thus 'fall outside the human' (Butler 1990: 111).

The theory of performativity disclosed that gender is enacted in relation to norms. The idea of ecstatic relationality makes more explicit how this norm-governed enactment takes place in relation to others (widely conceived). As she puts it, gender is a 'passionate 
comportment, a way of living the body with and for others' (Butler 2009b: xii). In this sense, 'no one gets to have gender all on their own ... We can't - we don't, actually - make radical or self-sufficient decisions about who we want to be or how we are perceived or recognized' (Butler in Butler with Taylor 2009: 208). Rather how we appear to others is conditioned by gender norms. To be eligible for recognition, an embodied being has first of all to be intelligible to others as gendered - that is, gendered in a way that makes sense according to dominant gender norms. Those who are unintelligible in these terms are unrecognisable, they do not appear in public as legible subjects in their own right, in other words, and as a result have no 'place in the social order' (Butler in Butler with Taylor 2009: 208). Their lives are not worth protecting, sheltering, or sustaining; not 'liveable' as Butler characterises it. Theirs are disposable lives.

We have already seen that precarity for Butler signals a politically generated condition of heightened risk, jeopardy, and threat for specific populations. It is thus used by her to distinguish between primary vulnerability, the ontological condition of being given over to others shared by all, and concrete particular, historical conditions of insecurity and liability faced by some. At various junctures in her work, Butler furnishes examples of conditions that qualify as precarity: conditions of arbitrary state violence or failing social and economic support networks (2009a: 25-6; 2009b: ii; 2011a: 383); situations of war, occupation, imprisonment, and forced emigration (2012a: 12); exposure to unemployment or being part of an 'expendable' labour force (2012a: 12; in Butler and Athanasiou 2013: 43), all of which she describes as 'clearly aims and effects of neoliberal forms of social and economic life' (in Butler and Athanasiou 2013: 21).

While gender is a cleavage that cuts across all of the above, Butler also identifies specifically gendered examples of precarity in the condition of sex workers threatened by police harassment and 'street violence', those whose intimate and kinship relations are not 
recognised by the law, and populations whose non-conformity to gender norms means they are at 'heightened risk' of aggression and assault (2009b: ii). She even goes as far as to suggest that precarity is a 'rubric that brings together women, queers, transgender people, the poor, and the stateless' (Butler 2009b: xiii). In none of these discussions, however, does Butler ever explore in detail the actual mechanisms that give rise to the concrete precaritisation of a particular population beyond referring to it as a general 'political' process induced by 'police actions, economic policies, governmental policies, or forms of state racism and militarization' (Butler in Butler with Taylor 2009: 33). She appears to consider it sufficient for argumentative purposes simply to note that bodies are made precarious - or precaritised - politically in a variety of different ways.

Of course, it might be questioned whether it is viable to use a single word, precarity, to describe the distinctive and even radically dissimilar ways in which fleshy lives are rendered unrecognisable and thus unliveable; particularly, since this risks eliding the very significant differences in experiences of precarity undergone by diverse populations (Thobani 2007), and in overlooking the plural conditions of unliveability operative at any one time. I want to set aside these concerns in this chapter, however, in order to focus on how precaritised bodies are able to act politically and ethically. In the next section I explore how politics materialises both within and against precarity (Butler 2012a: 14), before turning in the final section to the question of the relation between precariousness, precarity and ethics.

\section{Performing politics in conditions of precarity}

In a number of places in her work, Butler draws attention to the interplay between two factors: precarity and performativity (see, for example Butler 2009b; and Butler 2012a). She is particularly concerned with what happens to performativity politically when precarity is the starting point. In one of these discussions, Butler indicates that performativity is for her 'an 
account of agency', while precarity refers to the conditions 'that threaten life in ways that appear to be outside of one's control' (2009b: i). Her interest in performativity in conditions of precarity might be recast, therefore, as a question about how it is possible for precaritised populations to act politically.

From previous work, we know that Butler regards the reproduction of gender as entailing what she has latterly defined as 'a negotiation with power' (Butler 2009b: i): a doing of gender norms that has the potential to re-do the norm in unanticipated ways or even, in some unspecified circumstances, to un-do the norm and thus (to borrow from Gender Trouble) to 'disrupt the categories of the body, sex, gender and sexuality and occasion their subversive resignification and proliferation beyond the binary frame' (Butler 1990: xxxi). The performativity of gender thus holds out the possibility, as Butler writes in 2009, of 'remaking ... gendered reality along new lines' (2009b: i); not an easy task to be sure given that performative agency inheres in reiterating the same norms that sustain the very thing in need of transformation, heteronormativity. Butler's discussion of precarity adds significantly to this discussion of performative agency.

In her Adorno lecture, she asks a particularly pertinent question: 'When being dispossessed in sociality is regarded as a constitutive function of what it means to live and persist, what difference does that make to the idea of politics itself?' (2012a: 16). Her answer, given later in the lecture, is that democratic struggle requires political resistance that is 'plural', 'embodied' and that will, in addition, 'entail the gathering of the ungrievable in public space' to demand liveable lives (Butler 2012a: 18, original emphases).

'Grievability' is something of an ambivalent term in Butler's work. The concept emerges from her discussion of deaths that have not been publically mourned or acknowledged, such as deaths from AIDS in the US in the 1980s, or those at the hands of American forces in Afghanistan and elsewhere after 9/11. Although Butler exhibits some 
interest in the role of obituary writing in regulating national identity (2004a), and in the reporting of deaths in the media, by and large she is not concerned with the specific practices that comprise the politics of grief and mourning (Honig 2013). 'Grievability' for her is, rather, shorthand for referring to liveable lives, lives that are supported economically, politically and socially (Butler 2012a). As she explains in Frames of War, grievability 'precedes and makes possible the apprehension of the living being as living' (Butler 2009a: 15). A grievable life is a recognised life. Conversely, a life that is not recognised as a life, a life that is devalued or unsupported, is, as Butler characterises it, a life that is 'ungrievable or dispensable' (Butler 2012a: 11). 'Grievability' thus functions in Butler's work in much the way that abjection (1993) and unintelligibility (1990, 2004a, 2004b) did previously: as a way to differentiate between lives that are eligible for rights, support, and recognition (grievable lives) and those that are not (ungrievable lives). ${ }^{13}$

Butler explains further how 'the ungrievable' are able to act politically by turning to Hannah Arendt's The Human Condition, from which she draws two ideas: politics as concerted action and the scene of appearance. 'When people gather to rally against induced conditions of precarity, they are acting performatively', Butler writes, 'giving embodied form to the Arendtian idea of concerted action'. At such times, the 'performativity of politics' emerges from, and in opposition to, conditions of precarity (2012a: 14). Political struggle is not on this quasi-Arendtian reading reducible to individual action; rather action is 'concerted' (or in concert) because it happens between participants in a struggle; and it occurs when 'bodies appear together' (Butler 2011b). This has a bearing on how Butler understands public space.

Calling (loosely) on Arendt, Butler surmises that public space as such does not exist. Instead when the 'new social movements' (2012a: 18) fighting against precarity demonstrate on the square or rally in the street they 'reconfigure the materiality of public space' (Butler 
2011b); by laying claim to that space, they constitute it as public. Public space - the polis in Arendt's discussion (1958: 198) - is not a physical location; it is the organisation of people acting in concert. This links with Arendt's idea of the 'space of appearance'. Arendt defines this as 'the space where I appear to others as others appear to me' (1958: 198). So, politics necessitates the space of appearance; and that space facilitates politics. For Butler, in contrast to Arendt, this space is irreducibly corporeal (2011b): a space where bodies appear to other bodies. ${ }^{14}$ It is vulnerability understood as sensate impressionability that enables this, that allows the corpus of the other to appear to us (and vice versa).

According to Arendt, however, certain categories of persons (slaves, barbarians, and foreigners) were excluded from the space of appearance in the classical polis; indeed, their very exclusion defined that space. Pondering this, Butler asks 'how do we make sense of those who can never be part of that concerted action'? Are the 'destitute outside of politics and power, or are they in fact living out a specific form of political destitution'? (Butler 2011b). The answer to this question is important because to concede Arendt's point is to construct certain forms of political agency and action as either pre- or extra-political. An example of such reasoning may be found, she suggests, in the work of Giorgio Agamben (1998) when he construes the excluded in terms of 'bare life'. Butler worries that this depoliticises the plight of those so-described and denies a way to discuss the modes of agency and action engaged in by them, for to her mind such populations are 'more often than not, angered, indignant, rising up, and resisting' (Butler 2011b).

In contrast, Butler proposes that the precarity of the ungrievable is bio-politically regulated; it is 'a state actively produced, maintained, [and] reiterated' (Butler in Butler and Spivak 2007: 10), often by governments though not exclusively. It is thus a state internal to politics and power. This is an important qualification for Butler because it allows exclusion to be considered as a political problem and it makes visible the forms of agency and resistance 
associated with and facilitated by it. While the ungrievable may be excluded from 'established and legitimate political structures', that is while they may be unrecognisable as 'subjects', they are not ipso facto excluded from politics per se. Preferring Foucault's biopolitical account to Agamben's discussion of bare life, Butler contends not only that a life without rights is still 'within the sphere of the political' but that far from being 'bare', the life of the stateless, the occupied, and the disenfranchised is, in fact, 'mired' in power (Butler in Bell 2010: 149).

Butler invites us to think about how it is possible for the ungrievable to lay claim to the public sphere - to (re)constitute it - by turning to another of Arendt's concepts, this time from The Origins of Totalitarianism, namely the 'right to have rights' (2004 [1951]). This is a right that comes into existence as it is exercised by persons acting in concert. It is the means, I suggest, by which performativity and precarity are conjoined. By way of illustration I want to examine an example alluded to briefly by Butler in 'Bodies in Alliance and the Politics of the Street' (2011b). This is the annual 'Walk against Homophobia and Transphobia' that takes place in Ankara, Turkey. ${ }^{15}$

Routinely fined for appearing in public, often beaten, including by the police, and with trans murders occurring on average once a month, the situation of trans persons in Turkey is, as Butler notes, highly insecure. ${ }^{16}$ In this context, occupying public space, both singly and collectively, is incredibly risky for members of this precaritised population; it exposes them - renders them vulnerable - to threats of routinised punishment, violence, and even death. Following Butler (following Arendt), we might thus conclude that trans persons are, in effect, denied the right to have rights. As effaced and delegitimated persons, they are precluded from the space of appearance and from the plurality that inaugurates that space.

This is important: they are precluded from that space but not permanently excluded from it. It is possible, politically, for trans persons, en masse, to lay claim to public space and 
to performatively enact the right to have rights - rights 'to place and belonging' and to 'appear as the gender we already are' (Butler 2011b), and to do so in ways that contest the heteronormative ontology that pathologises them by the way it regulates corporeal and morphological appearance. ${ }^{17}$ Physically occupying space (marching through carrying flags and placards) is, as Butler notes elsewhere, a form 'of critique that take shape as bodies amass on the street to articulate their opposition to contemporary regimes of power' (2012a: 17); a 'living practice of critique' (2012a: 11) oriented towards the assertion of the idea that persons, 'no matter how they are gendered ... are free to move without threat of violence' (2011b). ${ }^{18}$ The occupation of public space is thus a way not just to render trans persons publically visible and audible, or to dispute the precarity of their gendered position; it is, at the same time, a demand for a liveable life.

There are, of course, several issues raised by this discussion that warrant further attention, however, the one I want to foreground concerns the relation between ethics and politics. Butler's discussion of the space of appearance, action in concert, and the right to have rights illustrates how the 'ungrievable' might disrupt the field of power in order to make political claims, and to become political subjects (see Butler in Butler and Athanasiou 2013: 101). Notably, she does not say, however, that bodies must first be recognised for politics to occur. And, indeed, she cannot. For politics arising in conditions of precarity is precisely politics that seeks, amongst other things, to contest the terms of recognisability that position certain lives as precaritised and unintelligible. Instead, she charges only that the body has to appear sensately to someone else.

The primary focus of these discussions is on those demanding political rights or contesting the terms of recognition. What this leaves unanswered, however, is the place of the other in responding to these demands. In particular, what is it that disposes subjects, especially those constituted as protected or valued subjects, to ethical responsiveness? In 
what ways is the capacity for an ethical response impacted on by precarity? What enables the other to recognise as 'human' a person who was previously invisible to them as such?

\section{Practising ethics in conditions of precarity}

Precarity, as we have seen, is construed in terms of historically instantiated modes of vulnerability that produce certain populations as exposed; bodies that are bio-politically constituted as at risk - of violence, death, starvation, incarceration, and deprivation.

Vulnerability as receptivity to what is outside us, what I see as the second sense of the term at play in Butler's work, is by contrast the basis of political agency and, as we will see, ethical responsiveness. Part of what conditions our political and ethical receptivity in situations of precarity is an acknowledgement of existential precariousness. There is, however, a paradox here, for while Butler argues that 'precariousness has to be grasped not simply as a feature of this or that life, but as a generalized condition whose very generality can be denied only by denying precariousness itself' (2009a: 22), she also contends that 'as soon as the existential claim [that everyone is precarious] is articulated in its specificity, it was never existential. And since it must be articulated in its specificity [viz., as precarity], it was never existential' (Butler 2012c: 148). In other words, even as she proposes that existential precariousness is an effect of corporeal interdependence shared by all, she simultaneously avers that, in fact, precarity, unevenly distributed, is all there is for every articulation of precariousness is already an articulation of precarity.

This has a bearing on ethics. For if precariousness is precisely what is supposed to enable ethical responsiveness; in fact, is also what we are also ethically obligated to affirm (see Jenkins, 2009), and if we are always impinged upon, and may even be conditioned by, the operation of social norms and ways of differentiating between grievable and ungrievable lives, then it suggests to me that in practice we may be less open to some ethical demands 
than others. Especially, as Butler remarks in Dispossession, because of the way 'vectors of power get registered at the level of primary sensibility, taking hold in spite of us, animating us, and forming a near involuntary dimension of our somatic lives' (in Butler and Athanasiou 2013: 96). So, what interests me here is the tension between the moment of ethical solicitation, when an ethical demand impinges on the subject from the outside, and the capacity to respond to that impingement in determinate circumstances. This returns us to the question of 'appearing', which in Butler's understanding is 'always to appear for another' (2011b). In particular, I am concerned with how the normative frames defining who is human govern or encroach upon the ethical scene.

Distancing herself from Emmanuel Levinas, who according to Butler suggested that the ethical demand is 'framed and restricted in advance by certain notions of culture, ethnicity and religion' (2012b: 39) - his way of contending that the Palestinian had no face Butler charges that the 'life of the other ... is also our life' (2012c: 140). Ethics on her understanding is always an issue of an ethical relation: that is, all persons, whether we know them or not, are from the very beginning implicated in the lives of others, such that the " $I$ " is invariably implicated in the "we"" (Butler in Butler and Athanasiou 2013: 107). Ethical obligations, for Butler, are thus 'prior to any individual sense of self' (2012c: 141). The ethical relation precedes individuation and ethical responsiveness precedes ethical responsibility. Ethical obligations, including towards those who frighten or threaten us, are an ineluctable feature of unwilled cohabitation, another idea she derives from Arendt, ${ }^{19}$ and as such they are 'precontractual' and 'nonconsensual' (Butler 2012c: 143, 137). Ethical obligations, in other words, arise without our consent or without being willed by us, extend to those whom we may not know, and rest on modes of receptiveness that can neither be fully predicted nor controlled (Butler 2012c: 141-2). This is where, to my mind, matters get a bit more troublesome. 
The starting point for an ethical response when some form of ethical demand is made is thus not 'individual disposition' or 'personal morality'; ethics is not, in this sense, a private or individual matter. Rather it begins from 'the presumption of a constitutive sociality' (Butler in Butler and Athanasiou 2013: 107). To act ethically is to avow that 'I am my relation to "you" (Butler 2012c: 142). Ethics is thus an effect of dispossession, of ecstatic relationality. The ability to receive a call (possible because the respondent is 'already answerable' to the other) does not in itself guarantee a response, however. Rather we need to be 'moved' to act (Butler 2012c: 136). It is, she observes, 'only when we are sufficiently impressed by the injustice of some situation in the world that we are moved to change it' (Butler in Hark and Villa 2011: 198).

Here some comments Butler makes in relation to the process of politicization might point the way to what facilitates such movement. Politicization, she commends, might be understood as 'motivated by an intelligent vulnerability' that transforms receptivity into action (Butler in Hark and Villa 2011: 198). It is openness to the world that enables us to demand change; when that demand is made, receptivity is sustained as 'a condition and font of intelligence for social and political action' (Butler in Hark and Villa 2011: 199). Elsewhere she describes ethical obligation similarly: receptivity is not merely the precondition for ethical action; it is one of its 'constituent features' (Butler 2012c: 136). At first sight, the objection might be made that one of the shortcomings of Butler's investigation of ethics is that she does not make clear what kinds of ethical or affective work are necessary to be able to respond ethically to those who do not immediately 'appear' to us. Indeed, this is what I initially thought.

A closer reading of her work, however, suggests that in refusing to conceptualise ethics as the province of a 'ready-made subject' (Butler 2012b: 9), Butler is also jettisoning the idea that it is possible to 'prepare' in advance for, or to 'anticipate', the moment of ethical 
solicitation. The point is that ethical solicitation happens 'in spite of ourselves and quite apart from any intentional act', it is 'beyond our will', 'not of our making' (2012c: 135); when we respond 'despite' our egos (Loizidou 2007: 53). Ethical receptivity, furthermore, is largely non-consensual. This insinuates that it is precisely when we are 'moved'-overwhelmed, outraged, or impassioned - to act that it is possible to discern 'the working of an ethical obligation on our sensibilities' (Butler 2012c: 136). Ethics, in this sense, might therefore, be taken to signify the acts by which others ("those who are "not me") ) are acknowledged as having a 'place' in the world (Butler 2012b: 9). The implication of this reasoning is that the evidence of ethical responsiveness is ethical action but that it is impossible to know, categorically, what triggers that responsiveness in the first place beyond the general existential propensity for dispossession.

Vulnerability-as-impressionability is the wellspring for ethics but, to reiterate, ethical encounters only arise in specific, delimited, historical contexts, contexts structured by normative frames. These precaritised situations are conditions of inequality, in which specific populations, as Butler has it, are produced as ungrievable. Given her comments about the ways that the subject is constitutively opaque to itself (Butler 1997, 2005), and her remark, cited earlier, that social norms and ways of discriminating between grievable lives comprise a 'nearly involuntary dimension of our somatic lives' (Butler in Butler and Athanasiou 2013: 96), this implies that subjects might be in the unconscious grip of, for example, certain normative bodily ontologies that render them unable to recognise as human those particular bodies produced as unintelligible and ungrievable by that ontology. Consequently, at times, subjects might not be able to respond ethically to an unrecognisable other because they are unable to see the body before them or to hear its address.

In this context, it is surely not enough to contend that a shared experience, of for instance loss, might be a sufficient (though it might perhaps remain a necessary) resource to 
overcome this block - recall that in Precarious Life Butler remarks that 'Despite our differences in location and history, my guess is that it is possible to appeal to a "we", for all of us have some notion of what it is to have lost somebody' (Butler 2004a: 20) - for this immediately dislocates, dehistoricises, and elides the very specific experiences of loss undergone by different groups or persons. ${ }^{20}$ While an occasion of loss might help us acknowledge that 'we' are vulnerable (whoever 'we' are), there is nothing in this experience per se that necessarily guarantees that 'we' will be able to 'see' or 'recognize' another's loss as a loss. We have only to refer to an example Butler herself supplies of a failure to acknowledge loss to see this, the refusal of the San Francisco Chronicle to publish either the obituaries of, or memorials for, two Palestinian families killed by Israeli soldiers (2004a). Or, we might consider the campaign 'Humanize Palestine', designed to try to 'restore the humanity that is often stripped away when Palestinians are reduced to calculative deaths, forgettable names, and burned and mutilated bodies, rather than people who shared loved ones, stories, dreams and aspirations' (Humanize Palestine, n.d.). ${ }^{21}$ These are deaths that in given settings do not register as deaths, losses that do not count as losses. ${ }^{22}$

My point is not that Butler is unaware of the mechanisms whereby particular populations are dehumanised or, to borrow her terminology, 'derealized' (Butler 2004a), or that this impedes the ability to recognise or respond to loss. Quite the contrary. It is rather that she appears to rest her hopes for practising ethics in precaritized situations on the abstract potentiality for ethical openness that emerges from ecstatic relationality and existential precariousness. The problem is that it is not apparent exactly what, if anything, might be done to enable or encourage ethical action in conditions of precarity where the actual prospects for ethical responsiveness appear to be foreclosed. ${ }^{23}$ 


\section{Conclusion}

Butler's more intense preoccupation with ethics certainly does not, in my view, supplant or neutralise her concern with politics as some critics insist. As her discussions of grievability, and who counts as 'human' testify, she is acutely aware of the ethical factors at work in political interactions and of the politics that shapes ethical questions. This is visible in her discussion of the relation between recognition and recognisability. Nevertheless, there is a qualitative difference in her approach to the two. Although both share her dualistic account of vulnerability as both susceptibility to harm and an openness to the other, when she discusses politics, Butler attends to specific, historically instantiated biopolitical regimes or normative frames (such as the 'heterosexual matrix'); in short, she focuses on precaritisation, on the actual conditions within which political action (of whatever kind) takes place, including the material harms that attend certain modalities of embodiment and how bodies appear to one another in ways that facilitate concerted action.

When she turns to ethics, however, her analysis shifts. To be sure, her primary concern is with what I have referred to as practising ethics in conditions of precarity; how, that is, it is possible, for instance, to respond ethically to those whom normative corporeal ontologies constitute as unintelligible or ungrievable. Nevertheless, her theorisation of the conditions of ethical responsiveness tends to emphasise ecstatic relationality and primary vulnerability in the abstract; that is, it stresses existential precariousness rather than lived precarity. The effect of this abstraction is that it is not clear how in determinate conditions it is possible, if at all, to overcome the normative constrictions that prevent us receiving an ethical address from a body we cannot 'see', or in an idiom we cannot 'hear', or to experience corporeal vulnerability in a way that opens up, rather than closes down, the chance for transformation that Butler characterises as the chance to become human (2005: 136). 


\section{References}

Agamben, Giorgio (1998), Homo Sacer: Sovereign Power and Bare Life, transl. Daniel Heller-Roazen, Stanford: Stanford University Press.

Arendt, Hannah (1958), The Human Condition, Chicago: University of Chicago Press.

Arendt, Hannah (1977 [1963]), Eichmann in Jerusalem, Harmondsworth: Penguin Books.

Arendt, Hannah (2004 [1951]), The Origins of Totalitarianism, New York: Schocken Books.

Beltran, Cristina (2009), 'Going Public: Hannah Arendt, Immigrant Action, and the Space of Appearance', Political Theory, 37: 5, 595-622.

Bell, Vikki (2010), 'New Scenes of Vulnerability, Agency and Plurality: An Interview with Judith Butler', Theory, Culture, Society, 27: 1, 130-52.

Benhabib, Seyla (2013), 'Ethics without Normativity and Politics without Historicity', Constellations, 20: 1, 150-63.

Brophy, Enda and Peuter, Greg de (2007), 'Immaterial Labor, Precarity, and Recomposition', in Catherine McKercher and Vincent Mosco (eds), Knowledge Workers in the Information Society, New York: Lexington Books, pp. 177-91.

Butler, Judith (1988), 'Performative Acts and Gender Constitution: An Essay in Phenomenology and Feminist Theory', Theatre Journal, 40: 4, 519-31.

Butler, Judith (1989), ‘Gendering the Body: Beauvoir's Philosophical Contribution’, in Ann Garry and Marilyn Pearsall (eds), Women, Knowledge, and Reality: Explorations in Feminist Philosophy, London: Unwin Hyman, pp. 253-62.

Butler, Judith (1990), Gender Trouble: Feminism and the Subversion of Identity, London: Routledge.

Butler, Judith (1993), Bodies that Matter: On the Discursive Limits of 'Sex', London: Routledge. 
Butler, Judith (1997), The Psychic Life of Power: Theories in Subjection, Stanford: Stanford University Press.

Butler, Judith (1999), Gender Trouble: Feminism and the Subversion of Identity, Tenth Anniversary Edition, London: Routledge.

Butler, Judith (2000), 'Ethical Ambivalence' Ambivalence' in Marjorie Garber, Beatrice Hanssen, and Rebecca L. Walkowitz (eds), The Turn to Ethics, New York: Routledge, pp. 15-28.

Butler, Judith (2004a), Precarious Life: The Powers of Mourning and Violence, London: Verso.

Butler, Judith (2004b), Undoing Gender, London: Routledge.

Butler, Judith (2005), Giving an Account of Oneself, New York: Fordham University Press. Butler, Judith (2009a), Frames of War: When Is Life Grievable?, London: Verso.

Butler, Judith (2009b), 'Performativity, Precarity, and Sexual Politics', Revista de Antropología Iberoamericana, 4: 3, i-xiii.

Butler, Judith (2011a), 'Remarks on “Queer Bonds”, GLQ, 17:2-3, 381-87.

Butler, Judith (2011b), 'Bodies in Alliance and the Politics of the Street', \#Occupy Los Angeles Reader, 1-3.

Butler, Judith (2011c), 'Hannah Arendt's Death Sentences', Comparative Literature, 48: 3, 280-95.

Butler, Judith (2012a), 'Can one lead a good life in a bad life? Adorno Prize Lecture', Radical Philosophy, 176, 9-18.

Butler, Judith (2012b), Parting Ways: Jewishness and the Critique of Zionism, New York: Columbia University Press.

Butler, Judith (2012c), 'Precarious Life, Vulnerability, and the Ethics of Cohabitation', The Journal of Speculative Philosophy, 26: 2, 134-51. 
Butler, Judith and Connolly, William (2000), 'Politics, Power and Ethics: A Discussion Between Judith Butler and William Connolly', Theory and Event, 4: 2.

Butler, Judith and Spivak, Gayatri Chakravorty (2007), Who Sings the Nation-State?: Language, Politics, Belonging, Oxford: Seagull Books.

Butler, Judith with Taylor, Sunaura (2009), 'Interdependence', in Astra Taylor (ed.), The Examined Life: Excursions with Contemporary Thinkers, New York: The New Press, pp. 185-213.

Butler, Judith and Athanasiou, Athena (2013), Dispossession: The Performative in the Political, Cambridge: Polity.

Chambers, Samuel A., and Carver, Terrell (2008), Judith Butler and Political Theory, London: Routledge.

Gilson, Erinn (2011), 'Vulnerability, Ignorance, and Oppression', Hypatia, 26: 2, 308-32. Gregory, Thomas (2012), 'Potential Lives, Impossible Deaths', International Feminist Journal of Politics, 14: 3, 327-47.

Honig, Bonnie (2010), ‘Antigone’s Two Laws: Greek Tragedy and the Politics of Humanism', New Literary History, 41, 1-33.

Honig, Bonnie (2013), Antigone, Interrupted, Cambridge: Cambridge University Press. Humanize Palestine (n.d.), 'About Humanize Palestine', http://humanizepalestine.com/ (last accessed 25 September 2014).

Hark, Sabine and Villa, Paula-Irene (2011), 'Confessing a Passionate State: Judith Butler im Interview', Feministische Studien, 29: 2, 196-205.

See also Human Rights Watch (2010), 'Turkey: Stop Violence Against Transgender People', http://www.hrw.org/news/2010/02/19/turkey-stop-violence-against-transgenderpeople (last accessed 13 June 2014). 
International Gay and Lesbian Human Rights Commission (2009), 'Turkey: Change Law of Misdemeanors to End Abuse of Trans People', 19 September 2009, http://iglhrc.org/content/turkey-change-law-misdemeanors-end-abuse-trans-people (last accessed 13 June 2014).

Jenkins, Fiona (2009), 'Queering Foetal Life: Between Butler and Berlant', The Australian Feminist Law Journal, 30: 63-85.

Kania, Eliza (2013), 'Exercising Freedom: Interview with Judith Butler', Revolutions: Global Trends and Regional Issues, 1: 1, 32-41.

Knisely, Lisa C. (2012), 'Oppression, Normative violence, and Vulnerability: The Ambiguous Beauvoirian Legacy of Butler's Ethics', philoSOPHIA, 2: 2, 145-66.

Lloyd, Moya (1998-99), 'Politics and Melancholia', Women's Philosophy Review, 20, 25-43. Lloyd, Moya (2007), Judith Butler: From Norms to Politics, Cambridge: Polity.

Lloyd, Moya (2013), 'Heteronormativity and/as Violence: The “Sexing” of Gwen Araujo', Hypatia, 28: 4, 818-34.

Loizidou, Elena (2007), Judith Butler: Ethics, Law, Politics, Abingdon: RoutledgeCavendish.

Macpherson, C. B. (1962), The Political Theory of Possessive Individualism: Hobbes to Locke, Oxford: Clarendon Press.

Murphy, Ann V. (2011), 'Corporeal Vulnerability and the New Humanism', Hypatia, 26: 3, 575-90.

Neilson, Brett and Rossiter, Ned (2008), 'Precarity as a Political Concept, or, Fordism as Exception', Theory, Culture, Society, 25: 7-8, 51-72.

Puar, Jasbar (ed.) (2012), 'Precarity Talk: A Virtual Roundtable with Lauren Berlant, Judith Butler, Bojana Cvejić, Isabell Lorey, Jasbar Puar, and Ana Vujanović', TDR: The Drama Review, 56: 4, 163-77. 
Shulman, George (2011), 'Acknowledgment and Disavowal as an Idiom for Theorizing Politics', Theory and Event, 14:1.

Stark, Hannah (2014), 'Judith Butler's Post-Hegelian Ethics and the Problem with Recognition', Feminist Theory, 15: 1, 89-100.

Third International Intersex Forum (2013), 'Public Statement', http://www.ilgaeurope.org/home/news/latest/intersex_forum_2013 (last accessed 29 April 2014). Thobani, Sunera (2007), 'White wars: Western feminisms and the "War on Terror"', Feminist Theory, 8:2, 169-85.

Willig, Rasmus (2012), 'Recognition and Critique: An Interview with Judith Butler', Distinktion: Scandinavian Journal of Social Theory, 13:1, 139-44.

\footnotetext{
${ }^{1}$ There is a third idea that she is seeking to combat, which is that of invulnerability and sovereign mastery, which I do not explore in this chapter. See, however, Gilson 2011.

${ }^{2}$ The classic political theory text here is, of course, C. B. Macpherson's The Political Theory of Possessive Individualism (1962).

${ }^{3}$ Butler notes that she derives the idea of $e k$-stasis 'to point out, as Heidegger has done, the original meaning of the term as it implies a standing outside of oneself' (2004b: $258 \mathrm{n}$. 7). ${ }^{4}$ In The Psychic Life of Power, Butler argues that the result of this disavowal is that the subject is constitutively opaque to itself; there are aspects of who it 'is' that are unknown and unknowable to it.

${ }^{5}$ To be fair to Murphy, she does note in passing that vulnerability makes bodies available not only for violence but also for care (2011: 579) though she does not pursue this insight. ${ }^{6}$ In addition, the body might itself be an instrument of violence, physical harm, threat, or
death-dealing against others.
} 
${ }^{7}$ In Antigone, Interrupted Honig acknowledges that Butler 'mentions in passing' that passion and love share a similar ecstatic 'structure' to mourning, and that she also 'thematizes the idea of a "livable life"'; Honig nevertheless concludes that Butler's 'affective repertoire ... is largely oriented to loss' (2013: 44).

${ }^{8}$ Although as Catherine Mills (this volume) shows, Butler is not always consistent in her usage of this distinction.

${ }^{9}$ In much of this wider literature reference is made to 'precarization' rather than to Butler's preferred 'precaritization'.

${ }^{10}$ Precarity has also been linked to political protests designed to 'make visible' forms of labour (and the labourers) rendered invisible by dominant modes of capitalist production, the most cited of which are the EuroMayDay parades that have taken place annually in various venues across Western Europe since 2001 (see, for instance, Brophy and de Peuter 2007: 184-5).

${ }^{11}$ Brandon Teena, a trans man, was murdered in Nebraska in 1993; Mathew Shephard, a gay man was murdered in Wyoming in 1998; and Gwen Araujo, a trans woman, was killed in California in 2002. For a discussion of the Araujo case that examines themes pertinent to those discussed in this chapter see Lloyd 2013.

${ }^{12}$ David Reimer, whose story is probably better known as the 'John/Joan case', was born a biological male but, as a result of a bungled circumcision operation when he was eight months old, was raised female under the supervision of psychologist John Money at Johns Hopkins University. It was Money's contention that a person's gender identity was the result of cultural conditioning. Further Money claimed that provided sex (re)assignment was completed by the time a child was two and a half years old, it ought to be able to be socialised into a gender different from the one assigned at birth without adverse effects. The 
evidence from Reimer, who eventually spoke out about his experiences, and who began living as a man, was that Money was wrong. Reimer committed suicide at the age of 38 . ${ }^{13}$ The concept of grievability, I want to suggest, is better understood in relation to precarity, and in particular to how specific populations are disposed to it, rather than to either mortalism or finitude per se, as for instance championed by Honig (2010, 2013) or Shulman (2011). To read Butler as a mortalist humanist or as advancing an ethics of finitude risks side-lining her interest in the conditions of liveability, and neglecting the dualistic nature of vulnerability as the condition for suffering and deprivation but also for politics (and ethics).

${ }^{14}$ Although it is beyond the scope of this chapter to pursue the comparison any further, Butler is endeavouring here to distinguish her understanding of the space of appearance from Arendt's (see Butler 2011b; 2012a). For Butler the space of appearance is 'a necessarily morphological moment' where the corpus appears, not just to act and speak (as for Arendt), but also to suffer, to labour, to move, to gesture, to join with others, and 'to negotiate an environment on which one depends' (2011b). So where Arendt consigned particular features of corporeal life (to do with survival) to the private sphere, separate from the political, Butler regards them as pertinent political considerations when they point to the precaritisation of whole populations. This latter point is important because it is often the government of corporeal appearance that is at stake for precaritised groupings.

${ }^{15}$ It was not only trans individuals that appeared on the street, of course. Another example Butler cites more than once concerns the singing, in Spanish, of the American national anthem by 'illegal' immigrants in California in 2006; see, for instance, Butler and Spivak 2007; Butler 2009; also Beltran 2009; and Jenkins (this volume).

${ }^{16}$ According to the International Gay and Lesbian Human Rights Commission, in March 2005 the Law of Misdemeanors (No. 5326) was introduced, which allows the police 'to fine or otherwise penalize Turkish citizens on a variety of charges, none of which are defined 
explicitly under the law'. This has resulted in transgender people in Ankara allegedly being fined 140 lira, and then being physically brutalised while in custody (2009). See also Human Rights Watch 2010.

${ }^{17}$ It is not enough for the ungrievable merely to refuse a particular way of life or to seek to assimilate to existing norms, what she describes in Precarious Life as 'a matter of a simple entry of the excluded into an established ontology' (Butler 2004a: 33). What is required is 'an insurrection at the level of ontology' (Butler 2004a: 33).

${ }^{18}$ For further consideration of the idea of critique in Butler's work see Jenkins, this volume ${ }^{19}$ The basis for this idea is Arendt's contention in Eichmann in Jerusalem (1977 [1963]) that Eichmann believed he could choose with whom to co-habit the earth, a view Arendt disputed; for her, according to Butler's reading, cohabitation was not a choice, it was an inescapable condition of social and political existence. See Butler 2011c; $2012 b$.

${ }^{20}$ There is not space to pursue this discussion here, but I think that Lisa Knisely is right to raise questions about the ways in which Butler 'runs the risk of reinscribing the specifics of a particular historical and political context', namely that of 9/11, a time when 'so many people were arguing for the kind of political response ...that was built specifically on the denial' of vulnerability and interdependence, into 'an oppressive ethical command' operative at all times and in all places (2012: 154, original emphasis).

${ }^{21}$ I am current engaged in studying this campaign as part of the research project 'Who counts? The political problem of the "human"', funded by the Leverhulme Trust.

${ }^{22}$ In the case of the San Francisco Chronicle, the setting is the US; in the case of 'Humanize Palestine', according to the campaign website, the setting is the Western media. For an important discussion of the way that Butler's work appears to foreground the experience of the (white) American subject in terms of loss and grief see Thobani 2007; see also Gregory 2012. 
${ }^{23}$ This is where Thobani's (2007) discussion has particular purchase. 